\title{
LOCAL COUNCILS AND LOCAL SERVICES
}

\section{Hal Colebatch*}

\section{The "Problem" of Rural Local Government}

Ten years ago, it was a commonplace of writings on politics and administration in underdeveloped countries that there was an urgent need to build up strong systems of local government based on popularly-elected councils at the local level. In some cases, this was in part a response to decolonisation: it was felt that as the expatriate generalist administrators withdrew, they would have to be replaced by different sorts of governmental structures which would be able to command a wider popular acceptance of their actions. And in the broader perspective, local government was seen as contributing to a wide range of general governmental aims, a belief which was summarized by the title of one of the best-known books on this theme: Democracy, Decentralisation and Development, Maddick, 1963.

Today, there is less confidence in representative local institutions. In a number of African and Asian states, elected local councils have been abolished, stripped of their powers, or brought under administrative control. Even among those who previously championed the cause of decentralisation, the devolution of powers to elected local authorities is said to have "failed"; the councils, it is said, were inefficient and corrupt, and by their parochialism hindered the "nation-building" activities of the central government. The latter was, therefore, compelled to intervene to restrain or even abolish the councils.

There are, of course, counter-arguments to this theme. It is argued, for instance, that councils were given enormous responsibilities but inadequate resources, and that the actions of central governments tended to reduce, rather than strengthen, the capacity of councils to meet their responsibilities. But we are unlikely to reach an understanding of the process involved simply by comparing the

\footnotetext{
* Hal Colebatch was a Research Officer at the Institute of Development Studies,
} from December 1971 to May 1973. 


\section{LOCAL COUNCILS AND LOCAL SERVICES}

arguments of the opposing sides : what is needed is a series of case studies to show why, in specific political contexts, decentralised institutional structures did not prove durable. This paper is drawn from one such case study, in Kenya, and is based on research carried out in Kenya between 1971 and 1973 .

The Institutional Framework in Kenya

The main services devolved to representative local bodies in Kenya were primary education, minor roads and health services below the hospital level. In the rural areas, these were the responsibility of the county councils, which were established at the district level (with two exceptions) to succeed the former African district councils and European county and district councils. Districts range in size from 214 to $77,900 \mathrm{sq} \mathrm{km}$ (median size $5,800 \mathrm{sq} \mathrm{km}$ ) and in population from 22,400 to 782,600 (median 185,000 ). Most councillors are chosen by direct election from single-member constituencies, although there have been no elections since 1968, and no contested elections since 1966. There is a small number of nominated members, and the district commissioner (DC) has regained his seat on the council (having lost it between 1963 and 1964), though he no longer chairs the meetings or has a formal veto over its activities, as his colonial predecessor did.

When the councils were responsible for these services, the actual control was in the hands of an officer-in-charge (OIC), variously termed the county education officer, medical officer of health, or works officer, who reported to a specialist committee of the council; the committee's decisions then had to be ratified by the full meeting of the council. While these OICs were, in formal terms, servants of the council, in the cases of education and health services, the OIC was a central government official, posted (not seconded) by his ministry to the council, responsible to the ministry as well as the council, and liable to be transferred to another post at the ministry's discretion. Only the roads OIC was unambiguously a council employee.

During this time, there was considerable expansion of these services,

1 A preliminary report on this research is contained in IDS Discussion Paper no. 38, (Colebatch, 1974a); a fuller analysis can be found in Colebatch, 1974b. 
particularly primary education, but the councils' handling of them was often criticised - for inefficient administration, for poor service, for parochialism, for corruption, but above all, for their financial performance. Councils appeared to be perennially on the verge of bankruptcy, failing to pay employees' wages (particularly teachers) on occasion, and sometimes dismissing teachers when funds were insufficient to pay them.

Giving the "financial crisis" of the councils as the major reason, the central government announced in October 1969 that these three services would be taken over by its own ministries. After this transfer of functions, the councils remained in existence, but their importance was greatly diminished and they had no direct voice in service operation, apart from the presence of the council clerk on the District Education Boards which were set up three years later.

The question is, of course, how to explain this pattern of change. Explanations have been sought in a number of directions, of which three seem to be of particular importance: the actual operation of the services, the nature of the financial arrangements supporting them, and the broader pattern of political and administrative change in Kenya. I will consider these in turn.

\section{Service operation}

As I have mentioned, the quality of these services during the county council period (1964-69) was often criticised and the transfer of functions is often explained in these terms: the councils were running the services badly, therefore it was necessary for the central government to take them over (and, by implication, to run them well). To adherents of this view, the real question about service operation is simply "Does the central government run them better than the councils did?"

In many respects, though, this is the wrong question, since it ignores the extent to which the central government was involved in the operation of these services before the transfer of functions. W'e have already noted that in the cases of education and health services, the OIC was a central government official. The medical officer of health, in particular, performed a wide range of functions for which 
he was reponsible only to the ministry. And primary education was subject to central government regulation in a number of important respects: syllabi, teacher training, examinations and, above all, progress from primary to secondary school. In fact, for these two services, it is probably more accurate to speak of services under broad central government control, but subject to county council pressures at certain critical points - in particular, over questions of service expansion.

This does not apply, however, to roads, where for a number of reasons, there was a much clearer distinction between the central government service and that of the councils. One important factor here was the fact that it was convenient for the central ministry to limit its role to that of providing a high-standard trunk road service. Another was that the council services were constantly dealing with "microdecisions" about small, marginal changes in service provision - e.g. whether to send a grader to work on one untrafficable road or on another - which were of vital importance to their clients. A third was that council road staff were less insulated from the political control structure than either their central counterparts or council staff in the other services. With roads, therefore, the councils were more clearly in control, and offered a more distinctive service - less clearly defined in its scope, and more responsive to pressures from councillors, than the other services.

Given the extent of central control before the transfer, it is not surprising that there was no major change in the operation of the education and health services after it. The control of the OIC was strengthened, and the institutional channels for the expression of client interests restricted, by the effective abolition of the education. and health committees of the councils. But there were other channels, and the OIC found that some areas of control still eluded him. Demands for school expansion were put directly to the OIC, and in the context of the whole Kenyan political structure, were difficult to resist. And he was no more able to amalgamate or close schools with low enrolments than he had been before the transfer: he had the formal powers to do so, but not the political support needed. Client pressures on the health services continued to grow, with "self-help" being used as a means of making a demand for service 
expansion: local leaders would organise the construction of a building, describe it as a "self-help health centre", and press the central government to "take it over". In this process, the district OIC was often by-passed, and appeals made direct to the ministry.

In the roads case, the transfer brought more changes. The ministry sought to make the local service more "professional": senior ex-council staff were transferred to other districts to break personal links between clients and service officials, new equipment was brought in and new procedures introduced, and the boundaries of the service clearly defined. This last step, however, was resisted not only by clients and their representatives, but also by a number of other officials, since it excluded from the possibility of service a wide range of roads which had received occasional attention from the councils, and also greatly reduced their own possible influence over the service. The ministry resisted pressures to be more "flexible" at the local level, but was eventually obliged to accept the creation of Rural Access Road Units (RARUs). These were set up to offer the sort of marginal service which the ministry itself was trying to avoid, and while they were located within the ministry, their operations were subject to the effective control of the district commissioner i.e., control was not vested in the "professionals".

Even from this brief discussion of service operation under council and ministry, it is clear that there was a good deal of continuity before and after the transfer, particularly in the cases of education and health services, and that where major changes did occur (in the case of roads), they were sometimes dysfunctional and led to compensating changes in the form of the establishment of the RARUs. This proposition is unremarkable in itself, but important in the context of the argument that the cause of the transfer of functions was the poor performance of the councils as service operators: if this were so, one would expect to find significant changes in service operation after the transfer. In fact, it is difficult to find evidence of internal pressures within the services that compelled the central government to take over responsibility for them. 
Financial Considerations

Finance was undoubtedly the most controversial aspect of service operation under the councils: the councils were accused of extravagance, financial irresponsibility and corruption, and in turn accused the central government of starving them of the funds necessary to carry out their functions. Councils frequently experienced spectacular "financial crises", during which staff (especially untrained teachers) would be dismissed and schools and dispensaries closed, for want of funds.

These "crises" were often held to be evidence of the financial incompetence of the councils, and hence of the need for the central government to take responsibility for these services. But the explanation is more complex. It must be noted that while in theory councils were autonomous bodies, most of their sources of revenue were controlled by the central government. Graduated personal tax accounted for a quarter of council revenue, but the tax rate was set by the central government, and the tax itself collected by government, not council officials. Moreover, the central government on several occasions reduced the tax rates to buy political support. Another major revenue source was school fees, and these too could not be changed without central government approval - which was not given. The central government also abolished other council revenue sources, such as dispensary fees and the maize cess, neither consulting the councils beforehand nor compensating them afterwards.

The councils were therefore dependent on their own accumulated reserves, and on central government grants, to finance the continued provision of services. And central grants were not seen by the government as fixed and predictable revenue sources for the councils, but as ex gratia payments to enable councils otherwise unable to balance their budgets to do so. Until 1967 there was not even a formula for allocating grants; in that year, one was introduced (at least on paper) but in May 1969 it was admitted that "because of a shortage of funds", grants were only being paid to local authorities "which had an actual cash shortage". 
The message for councils was clear: those that scrupulously tailored their expenditure to their revenue would largely be left on their own, whereas those which found themselves in a financial "crisis" would be bailed out by the government. It is scarcely surprising, therefore, that "crises" came to be increasingly frequent and prolonged, and that by 1968 , the estimated aggregate expenditure of the councils exceeded their aggregate revenue by over $£ \mathrm{~K} 2.8 \mathrm{~m}$. What was developing, in fact, was a regular system of "crisis financing": a council would, through a combination of necessity and design, exhaust its reserves so that if, for instance, it failed to receive a grant to which it was entitled, it would suffer an immediate cash crisis. It would then lay off teachers, provoking union protests in Nairobi which would lead to inter-ministerial negotiations and ultimately to the release of more funds for the council.

"Crisis financing", therefore, was not necessarily a sign of financial incompetence on the part of the councils; in fact, it was the most rational response to the rules of the game as they then applied. As a problem, it was "solved" by the transfer of functions, just as the problem of a sore thumb is "solved" by the amputation of the arm: the question is why the government chose this sort of response, rather than other alternatives such as reallocation of revenue sources, or application of more stringent rules about grant allocation. This will become clearer in the next section. As for the volume of spending on these services, the evidence suggests that to some extent it increased at a faster rate after the transfer, but not as an immediate consequence: most of the increase, in fact, could be attributed to specific items like increases in teachers' pay and the spending of the proceeds of an IBRD loan for new road plant. In general, there is little evidence to suggest that the transfer was primarily aimed at providing more money for the services.

\section{Political Change}

The discussion so far, like most analyses of this question, has focussed on factors within the services themselves - the administration and financing of the service agencies. But it has yielded no clear rationale for the transfer of functions, and this, I would argue, is because the transfer can only be understood in the context of the pattern of political change in Kenya over this period. 
It is important to remember that the original decision to vest these services in the county councils was part of a wider strategy aimed at reducing the power of the central government. KADU, the minority party, had demanded a regionalist constitution, with substantial devolution of power from the centre to the regions, and from the regions to the councils - in other words, a radical transformation of the structure of the colonial state. This was reluctantly accepted by the KANU government as the price of independence, but not as the basis of a permanent constitution, and within twelve months of independence the regional governments had effectively been abolished, and the centralised structure of government restored. In particular, the provincial administration regained the pre-eminence it had enjoyed in the colonial political order, and provincial and district commissioners were designated the personal representatives of the president in their areas.

This constitutional change had been made possible by the merger, in November 1964, of the two parliamentary parties, KANU and KADU. An opposition party, the Kenya People's Union, was formed in 1966 but was subject to extensive harassment by the government and eventually banned in 1969 . The government has since made it quite clear that although the law may permit the formation of political parties, the government will not: in June 1974 the president warned that anyone who tried to form an opposition party to contest the forthcoming parliamentary elections would be "physically crushed". The government has also extended its control over other forms of organisation which might be used to present an organised challenge to the government. The colonial controls over trade unions, co-operatives and other associations have been retained and strengthened, and steps have been taken to achieve effective government control over new forms of organisation such as self-help groups.

In addition, the government has secured a critical role for itself in the allocation of economic opportunities. Land acquired from departing white settlers and subdivided for settlement is distributed by the government, and allocated by bodies chaired by the district commissioner. Other government agencies allocate licences for retail trade, distributorships for wholesale trade, and the loans which 
enable Africans to break into the protected commercial sphere. The government wields the carrot as well as the stick.

The pattern, then, is of a general expansion of state power over a wide range of economic, social and political life, together with the repression of possible organisational bases for challenging those presently in control of the state structure. The consequence is a form of "consultative politics", in which a generalist administrative hierarchy - the provincial administration - consults with local notables at various levels to secure their acquiescence in governmental activities, conceding in return some of the favours which they seek on behalf of themselves and their clients.

In this context, the county councils represented an area of activity not fully subordinated to the machinery of state control, and there was constant pressure from the provincial administration for full control over the councils - e.g. by trying to wrest from the ministry of local government the right to approve council estimates, and by trying to secure for the DC a general veto over council activities. The problems of the council services were used as a lever to try to strengthen the dominance of the DCs over the councils, and while the problems were usually real enough, they were often only the issues over which an underlying structural conflict was fought out.

\section{Policy Implications}

This analysis carries a number of policy implications in respect of the Kenyan situation in particular. It is clear that the "problem" of the county council services was not primarily about efficiency in service provision, or the adequacy of service finance, although these were important factors. The real question was what sort of response would be made to operational and financial strains in service provision by decision-makers in a state structure which was very much concerned to expand its own authority. As we have seen, the response made the transfer of council functions to the ministries - was primarily a change in political control: it did not necessarily result in any changes in service operation of finance, and where it did, the changes were sometimes unanticipated and dysfunctional. The perspective which sees the "problem" as stemming from the inadequacies of the councils, and forcing the central government to "take action" is 
quite misleading. The government itself was the cause of much of the problem, and its "solution" was clearly geared to its own interests in expanding state authority. (More detailed policy implications for Kenya are discussed in Colebatch, 1974a, especially chapter ten).

There are also a number of more general policy implications. One is that any analysis of the "local service problem" must specify very precisely the relationships involved. In the Kenyan case, primary education and health services were said to be run by the councils, but in fact the role of the central government was probably as prominent as that of the councils. And for the most part, the ministries operated with the same staff and facilities as the councils had before them. For these two services, therefore, the most significant impact of the transfer of functions was the way it redefined the relationship between the OIC and the councillors - still an important change, but not as complete a break with the past as was sometimes assumed.

In particular, the term "local" needs to be kept within a specific context of political and administrative relationships. There is a tendency for "local" to be seen as an absolute, definitive term: "local" services are inefficient, "local" politicians are parochial and corrupt - as though these were inherent characteristics, independent of any organisational relationship. In this sort of analysis, council financing in Kenya is described as "chaotic", and the fact that it was rational and effective in the context of the total system is conveniently overlooked. Similarly, the massive expansion of secondary schooling is said to derive from "local" pressures, and not from the whole structure of reward in Kenyan society, which allocates to a secondary school-trained employee an income ten or fifteen times that of the average farmer, and which rests on policy decisions taken at the national level.

One final point which needs to be made is that local service structures have to perform rather different tasks from those of the ministeries in the national capital. When comparing alternative service structures, therefore, the real comparison is not between local authorities and the ministries, but between local authorities and the sort of structures that ministries establish at the local level to deliver services - including machinery for client contact and service 
definition as well as the "technical" task of actually giving the service. The Kenyan roads example is a case in point: the ministry replaced the councils' road organisations with

hierarchically-controlled structures which were better at performing the technical task of road maintenance but less effective at securing broad agreement (among clients, representatives and other officials) over questions of service definition, procedures and priorities: which roads should receive maintenance, when, and to what extent?

Eventually a separate road organisation was set up which would be able to establish closer rapport with clients and the governmental structure, and in so doing, shield the ministry from some of the pressures on it from these groups.

And this, of course, illustrates the whole point of rural local government as a service agency: it offers one way of coping with the problem of marginal service. The major service needs in any field, like trunk roads, are easy to see: it is the minor ones, like simple feeder roads, which pose the greatest problems for the service agency. The agency has to face the question of whether service at this very low level is warranted at all, and if so, where the service (the road, the school or the dispensary) is to be located. And while these decisions are marginal to the service agency, they are of great importance to the clients of the service, and in underdeveloped countries, of ten of critical importance: the question of whether a community has, or does not have, a school or a feeder road can mean a whole qualitative change in the sort of life open to its members.

Local government, then, is one institutional way of dealing with the problem of marginal service: it provides for clearly-designated client representatives, and for service officials to be (to a greater or lesser extent) subordinate to them. It may or may not prove to be an effective way of settling questions of marginal service, but abolishing local authorities does not make these questions go away: they remain to confront the central service face-to-face, as it were. This was the problem which the Kenyan central road organisation faced after the transfer of functions: it had to make decisions about a multitude of tiny road problems from which it had previously been insulated by the existence of the county councils. And the outcome was the creation of a new road organisation specifically for these marginal 
questions, which will presumably be as "inefficient" as those of the county councils were said to be. If there is a moral for policy-makers in this, it is that it is easier to see the defects of local authorities than to work out how central agencies can at the same time maintain their technical "efficiency" and deal adequately with the problems of service provision at the margin.

\section{References}

Colebatch, H.K., 1974a "Government services at the district level in Kenya”, IDS Discussion Paper no. 38

Colebatch, H.K., 1974b Local services in the governmental process in Kenya. D.Phil. thesis, University of Sussex

Maddick, Henry, 1963 Democracy, Decentralisation and Development, Asia Publishing House, Bombay. 